\title{
Keputusan Pembelian dan Kepuasan Konsumen Dipengaruhi Variabel Lokasi, Pelayanan, Kualitas Produk, Nilai Emosional, dan Disain Interior yang Berdampak pada Tingkat Pembelian
}

\author{
Bahri \\ Kewirausahaan, Universitas Widya Mataram, Indonesia \\ Korespondensi penulis: bahri@widyamataram.ac.id
}

\begin{abstract}
This research is motivated by the growing of online businesses that have an impact on decreasing income of retail businesses. In order to survive, a retail business have to implement strategies that can increase purchases and provide satisfaction to consumers. This study aims to determine the effect of location, service, product quality, emotional value, and interior design variables on purchasing decisions and also customer satisfaction for increasing purchases, and testing the effect of purchasing decisions on customer satisfaction at Gardena Department Store \& Supermarket. This type of research uses quantitative descriptive. The sampling method is non-probability sampling and using purposive sampling technique. The data that have been collected then analyzed using the statistical hypotheses test method consist of multiple linear regression analysis, $t$-test, and f-test. The partial results of the study indicate that the location, service, and product quality variables have positive and significant effects on purchasing decisions and customer satisfaction. While the emotional value and interior design variables have no partial effects on purchasing decisions and consumer satisfaction. Purchasing decisions has a significant positive effect on customer satisfaction. Simultaneously, the variables of location, service, product quality, emotional value, and interior design have positive and significant effects on purchasing decisions and customer satisfaction at Gardena Department Store \& Supermarket. The results of this study can be used as an implication for company management that should continue to improve service, product quality, and need to pay attention to location, especially access and large parking lots so that consumers decide to make purchases and get satisfaction from the products, resulting an increase in consumer purchases at Gardena Department Store \& Supermarket.
\end{abstract}

Keywords: Location, Service, Product Quality, Emotional Value, Interior Design, Purchasing Decisions, Customer Satisfaction.

\begin{abstract}
Abstrak: Penelitian ini dimotivasi oleh pertumbuhan bisnis online yang berdampak pada penurunan pendapatan bisnis ritel. Untuk bertahan hidup, bisnis ritel perlu menerapkan strategi yang dapat meningkatkan pembelian dan memberikan kepuasan kepada konsumen. Penelitian ini bertujuan untuk mengetahui pengaruh lokasi, layanan, kualitas produk, nilai emosional, dan variabel disain interior terhadap keputusan pembelian dan juga kepuasan pelanggan untuk meningkatkan pembelian dan menguji pengaruh
\end{abstract}


keputusan pembelian pada kepuasan pelanggan di Gardena Department Store \& Supermarket Yogyakarta. Jenis penelitian ini adalah diskriptif kuantitatif. Metode pengambilan sampel adalah non-probability sampling dan menggunakan teknik purposive sampling. Data yang telah terkumpul, kemudian dianalisis menggunakan metode uji hipotesis statistik yang terdiri atas analisis regresi linier berganda, uji t, dan uji F. Hasil pengujian parsial pada penelitian menunjukkan bahwa lokasi, layanan, dan variabel kualitas produk memiliki pengaruh positif dan signifikan terhadap keputusan pembelian dan kepuasan pelanggan, sedangkan nilai emosional dan variabel disain interior tidak memiliki pengaruh terhadap keputusan pembelian dan kepuasan konsumen. Keputusan pembelian memiliki dampak positif yang signifikan terhadap kepuasan pelanggan. Secara simultan, variabel lokasi, layanan, kualitas produk, nilai emosional, dan disain interior memiliki pengaruh positif dan signifikan terhadap keputusan pembelian dan kepuasan pelanggan Gardena Department Store \& Supermarket. Hasil penelitian ini memberikan implikasi bagi manajemen perusahaan agar terus meningkatkan layanan, kualitas produk, dan perlu memperhatikan lokasi, terutama akses dan lahan parkir yang luas, sehingga pembelian oleh konsumen di Gardena Department Store \& Supermarket dapat meningkat.

Article Info:

Received: October 5, $2018 \quad$ Accepted: November 19, 2018

Available Online: December 13, 2018

DOI: http://dx.doi.org/10.30588/jmp.v8i1.388

\section{LATAR BELAKANG}

Di tengah pertumbuhan ekonomi Indonesia yang terus meningkat setiap tahunnya, ada baiknya perusahaan segera menyiapkan beberapa strategi bisnis dalam upaya untuk meningkatkan penjualan dan menjaga kestabilan perusahaan. Pada tahun 2018 ini, para pebisnis di Indonesia yang bergerak di bidang ritel menargetkan peningkatan usaha sebesar 9\%, walaupun faktanya adalah nilainya lebih rendah dari tahun lalu. Data dari Asosiasi Peritel Indonesia (Aprindo), peningkatan usaha di bidang ritel tahun 2018 ini mencapai angka 9\%, sedangkan pada tahun 2017 jumlah pendapatan bisnis ritel secara nasional meningkat sekitar 3,5\%. Menurut perkiraan Aprindo, nilai penjualan bisnis ritel di Indonesia pada tahun 2017 berada di angka Rp 221 triliun (Minimarketrak, 2017). Peningkatan dan perkembangan bisnis ritel di Indonesia pada tahun 2018 ini sangat berat. Perkiraan ini sesuai dengan hasil survei dan riset yang dilakukan oleh Bank Indonesia (BI) yang menunjukkan adanya perubahan terhadap tingkat penjualan bisnis ritel pada awal tahun 2018. Indeks Penjualan Riil dalam kondisi tersebut merupakan hasil kontraksi sebesar $1,8 \%$ (yoy), yaitu kenyataan sebenarnya pada bulan sebelumnya mengalami pertumbuhan dengan nilai sebesar 0,7\% (Setiawan, 2018).

Saat ini, banyak perusahaan swasta yang berskala nasional menerapkan teknologi informasi yang berkaitan dengan usaha ritel. Penggunaan dan penerapan teknologi dalam bisnis ritel di era milenial ini telah banyak menerapkan teknologi e-commerce (perdagangan elektronik) dengan tujuan untuk lebih mendekatkan diri mereka dengan konsumen. Di era Industri 4.0, para pengusaha ritel telah banyak melakukan perubahan dengan aplikasi internetd dalam usahanya. Kebiasaan konsumen di era sekarang ini lebih senang melakukan pembelian melaui online. E-commerce sebagai media transaksi perdagangan modern, yaitu setiap media elektronik terkoneksi jaringan internet, sehingga 
semua segmen konsumen dapat memanfaatkannya dalam melakukan transaksi perdagangan. Kenyataannya, konsumen sekarang paling senang melakukan transaksi jual beli secara online, karena keputusan melakukan pembelian secara online dianggap lebih mudah dan praktis. Indonesia mencatat pertumbuhan belanja online tertinggi di dunia, yaitu rata-rata sekitar 37\% per tahun sejak 2013 (Soesatyo, 2018). Pada tahun 2025, perkembangan ekonomi berbasis internet di Asia Tenggara diprediksi akan mencapai nilai US\$200 miliar per tahun (Lubis, 2017). Namun, prediksi angka di tahun 2025 tersebut dapat diraih dengan sangat cepat melebihi angka yang telah ditargetkan.

Industri ekonomi digital terus berkembang di tengah ketidakpastian global. Di sisi lain, pertumbuhan ekonomi berbasis konvensional, seperti ritel, akan semakin tergerus. Badan Penelitian dan Pengembangan Industri Kementerian Perindustrian memprediksi bahwa pertumbuhan transaksi perdagangan secara online atau $e$-commerce di Indonesia akan semakin pesat. Pada tahun 2025, Indonesia akan menguasai 52\% pasar perdagangan online di Asia Tenggara (Kumparan, 2017). Perkembangan e-commerce ini bisa menjadi ancaman riil bagi bisnis offline. Dalam hal ini, Gardena Department Store \& Supermarket berpotensi ditinggalkan oleh para konsumennya yang memutuskan melakukan pembelian kebutuhan melalui online dan berimbas pada penurunan pendapatan. Kenyataan ini sangat menarik untuk dikaji di tengah berkembangnya bisnis secara online, sehingga faktor apa yang perlu ditingkatkan dan strategi apa yang harus dilakukan oleh pebisnis ritel, seperti Gardena Department Store \& Supermarket untuk tetap eksis dan bertahan, serta mampu meningkatkan penjualannya.

Namun, tidak dapat dipungkiri bahwa masih ada masyarakat di Indonesia lebih cenderung dan lebih senang melakukan pembelian secara langsung, datang ke tempat berbelanja, dan sambil bersantai (perdagangan offline). Masyarakat masih mempercayai dan mengedepankan interaksi langsung dan ramah tamah dalam berbelanja. Menurut Best (dalam Safitri, 2017), nilai konsumen merupakan total benefit yang diperoleh konsumen dikurangi pengorbanan (biaya) mereka. Oleh karena itu, para pengusaha tidak boleh menunggu, tetapi mereka harus memiliki kesiapan dan kemampuan merancang strategi bagaimana melayani dan mempertahankan konsumen. Pengelola bisnis ritel, seperti Gardena Department Store \& Supermarket perlu melakukan antisipasi kebutuhan dan penyesuaian produk maupun fitur produk yang sesuai keinginan agar konsumen memutuskan untuk membeli secara langsung dan mencapai kepuasan. Keputusan konsumen dalam pembelian produk mempunyai ikatan yang sangat tinggi dengan penentuan lokasi pembelian. Lokasi pembelian yang akan dituju harus mudah dijangkau dan aksesnya tidak macet.

Selain lokasi yang jarak tempuhnya mudah, faktor lain yang menjadi pertimbangan konsumen pada saat berbelanja ialah pelayanan. Customer pada saat bertransaksi menginginkan pelayanan yang cepat tanggap, tepat, sopan, dan ramah. Keramahanan yang dimaksud ini ialah konsumen yang datang berbelanja merasa dihargai dan dihormati, sehingga timbul perasaan puas di benak dan hati mereka. Sesuai penjelasan Tjiptono (2001) yang dikutip oleh Rahman (2013), tujuan dasar bisnis ialah mampu menciptakan konsumen yang merasa puas.

Keberadaan Gardena Departement Store \& Supermarket dapat dikatakan sebagai salah satu wujud gaya hidup masyarakat kota besar. Yogyakarta sebagai kota pelajar tidak luput dari fenomena tersebut. Keberadaan beberapa bisnis ritel ini mendapat respon 
positif dari masyarakat. Pendiri Gardena Tan Ie Kong dan Indriyati didukung putera sulungnya Bintoro Sulaksono mengembangkan usahanya dengan membuka toko Vinolia di Jalan Urip Sumoharjo No. 37C pada tahun 1973 (Yogyakartagardena, 2018). Dari semula toko kecil terus berkembang paling cepat di kawasan tersebut. Sejak tahun 1973 Gardena Department Store \& Supermarket ialah salah satu supermarket utama yang menjadi pilihan masyarakat Yogyakarta dalam berbelanja untuk memenuhi kebutuhan (Gardenamagelang, 2011).

Karyawan Gardena Department Store \& Supermarket dalam bekerja sangat menjunjung tinggi nilai profesional dan selalu mengutamakan kepuasan pelanggan. Dengan adanya keputusan pembelian dan terpenuhinya kepuasan, maka akan berdampak pada adanya peningkatan pembelian. Dalam keputusan pembelian, kualitas produk yang dijual juga menjadi salah satu faktor penentu kepuasan konsumen. Dalam memberikan perasaan puas pada konsumennya, Gardena Department Store \& Supermarket merancang strategi yang adaptif untuk menghadapi pasar dan ancaman kompetitor. Strategi tepat dan cepat yang harus dimiliki tersebut adalah pelayanan karyawan yang cepat, produk bermutu, disain interior yang menarik dan nyaman, serta didukung lokasi dan akses jalan yang mudah dijangkau dan memberikan nilai emosional dalam berbelanja (Gudegnet, 2016).

Menurut Sweeney dan Soutar (2001) dalam Ridwan dan Palupiningdyah (2014), nilai emosional merupakan perasaan emosi positif yang muncul setelah mengkonsumsi produk yang sudah dibeli. Apabila konsumen merasakan perasaan positif (positive feeling) di saat membeli serta menggunakan barang yang dibeli, maka barang tersebut memberikan dampak timbulnya nilai emosional. Nilai emosional sangat penting diberikan kepada konsumen, karena rasa kepuasan saja tidaklah cukup. Konsumen perlu mendapatkan pengalaman yang berkesan pada saat atau setelah mengkonsumsi produk, agar mereka mau merekomendasikan kepada konsumen yang lain dan mengambil keputusan untuk melakukan dan meningkatkan pembelian di Gardena Department Store \& Supermarket.

Keinginan terbesar konsumen pada saat membeli barang adalah berharap mendapatkan perasaan senang, bahagia, nyaman, tentram, aman, dan perasaan dihargai. Namun, masalah yang dihadapi berdasarkan observasi di lapangan, konsumen beranggapan bahwa Gardena Department Store \& Supermarket: (1) lokasinya sangat strategis dan sangat mudah dijangkau, tetapi tempat parkir yang terbatas dan sering terjadi kemacetan lalu lintas di sekitarnya, (2) barang yang tersedia sangat lengkap, tetapi harganya relatif mahal dan jarang memberikan diskon, (3) pelayanan pegawai dirasakan masih kurang responsif, (4) kualitas produk yang dijual relatif masih kurang, dan (5) keadaan interior bangunan yang kurang baik karena disain interior masih model lama.

Kotler (2001) menjelaskan bahwa keputusan pembelian konsumen terhadap barang yang ditawarkan dapat dipengaruhi oleh beberapa faktor, yaitu harga, produk, pelayanan, dan lokasi. Perusahaan ritel seharusnya mampu bergerak cepat mengantisipasi perkembangan dan kemajuan usahanya, karena konsumen sekarang sangat selektif pada saat melakukan pembelian. Kepuasan konsumen ialah tingkat perasaan konsumen setelah membandingkan antara apa yang dia dapatkan dengan apa yang diharapkannya (Umar, 2005). Konsumen yang mendapatkan kepuasan dari nilai barang, sangat besar kemungkinannya menjadi konsumen dalam jangka waktu yang sangat lama. Selanjutnya, 
Irawan (2009) merekomendasikan lima faktor yang mempengaruhi kepuasan konsumen, yaitu kualitas produk, kualitas pelayanan, nilai emosional, harga, dan kemudahan.

Berdasarkan permasalahan dan uraian di atas, penelitian ini bertujuan untuk mengetahui keputusan pembelian dan kepuasan konsumen yang dipengaruhi oleh variabel lokasi, harga, pelayanan, kualitas produk, nilai emosional, dan disain interior yang berdampak pada peningkatkan pembelian. Kontribusi penelitian ini diharapkan mampu memberikan informasi yang jelas dan akurat kepada manajemen Gardena Department Store \& Supermarket, bahwa keputusan dan pembelian konsumennya dipengaruhi oleh variabel-variabel tersebut. Setelah konsumen mencapai kepuasan, apa dampaknya pada pembelian konsumen Gardena Department Store \& Supermarket.

\section{KAJIAN TEORITIS}

Menurut Kotler (2007), keputusan pembelian adalah tahapan-tahapan yang dilakukan konsumen sebelum memutuskan untuk melakukan pembelian produk, sedangkan Assauri (2004) menyebutkan keputusan pembelian ialah proses pengambilan keputusan pembelian terhadap apa yang ingin atau tidak dibeli, serta keputusan itu didapatkan dari kegiatan sebelumnya. Munandar (2001) menyatakan bahwa pengambilan keputusan pembelian terdiri atas upaya mengenali kebutuhan, mencari informasi, tahap evaluasi, dan melakukan seleksi sebagai alternatif, menyeleksi saluran distribusi, dan melakukan keputusan pembelian produk sesuai kebutuhan konsumen.

Schiffman dan Kanuk (2004) dalam Suhari (2008) menyatakan bahwa keputusan ialah tindakan dalam melakukan pemilihan dari beberapa alternatif pilihan, sehingga pada saat pengambilan keputusan konsumen harus mempunyai pilihan lain sebagai alternatif. Sebaliknya, jika konsumen tidak mempunyai pilihan lain, maka hal itu tidak bisa dikategorikan sebagai pengambilan keputusan. Selanjutnya, Dharmmesta dan Handoko (2000) menyatakan bahwa proses pengambilan keputusan pembelian produk dibagi ke dalam lima tahap (Gambar 1).

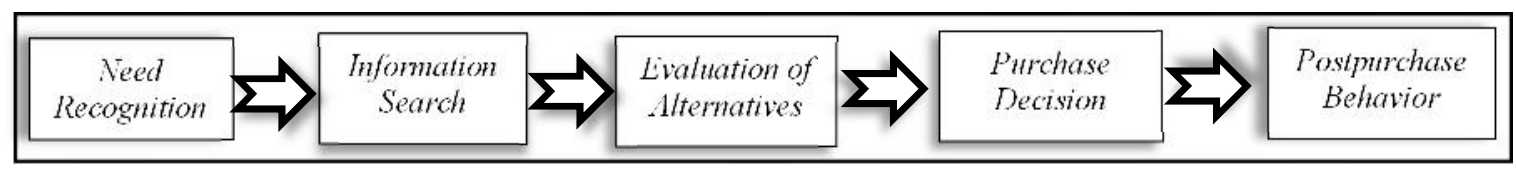

Sumber: Dharmmesta \& Handoko (2000).

\section{Gambar 1. Tahapan dalam Pengambilan Keputusan Pembelian Konsumen}

Tahap pertama dalam keputusan pembelian konsumen adalah need recognition. Tahapan ini adalah konsumen berusaha untuk mengenali adanya kebutuhan, yaitu dari adanya kebutuhan yang dirasakan dan kemudian berusaha untuk memenuhinya. Tahap kedua, information search ialah tahapan ketika konsumen berusaha untuk aktif mencari informasi sesuai dengan barang kebutuhannya. Pencarian informasi dilakukan untuk mendapatkan pengetahuan lebih banyak tentang produk yang akan dibeli. Tahap ketiga, evaluation of alternatives dilakukan setelah pencarian informasi. Konsumen akan menggunakan informasi tersebut sebagai perangkat untuk melakukan evaluasi. Menggunakan evaluasi alternatif bertujuan agar konsumen dapat menentukan kebutuhan produk yang diinginkan melalui keputusan pembelian. Tahap keempat adalah purchase 
decision, yaitu tahapan ketika konsumen memutuskan untuk melakukan pembelian produk sesuai kebutuhannya. Setelah konsumen melakukan pembelian, maka tahap terakhir berkaitan dengan postpurchase behavior, yaitu merasakan manfaat dan kegunaan produk yang dibeli, sehingga konsumen dapat merasakan kepuasan, apabila barang yang dibeli sesuai dengan keinginan dan kebutuhannya, dan ia bisa melakukan pembelian ulang pada masa berikutnya. Sebaliknya, jika barang yang dibeli tidak sesuai dengan kebutuhan, maka konsumen akan merasa kecewa.

Kotler (2004) dalam Putra dan Sunarti (2010) menyatakan apabila produk yang dibeli sesuai dengan kebutuhan konsumen, maka ia akan merasasakan kepuasan dari kinerja produk tersebut dan mampu mempengaruhinya untuk memutuskan pembelian ulang dan meningkatkan pembeliannya. Kepuasan konsumen ialah rasa emosional yang dirasakan konsumen dari dampak menggunakan produk atau jasa yang dibeli (Windasuri \& Hyacintha, 2017). Untuk mengukur kepuasan pelanggan, Roisah dan Riana (2016) menjelaskan bahwa pemasar dapat melihat kepuasan konsumen terhadap produk melalui nilai emosional, kepercayaan terhadap produk, dan menceritakan manfaat produk kepada orang lain. Di sisi lain, Widhiarsa (2011) dikutip dalam Simamarta dkk. (2018) menjelaskan bahwa dimensi yang digunakan untuk mengukur kepuasan konsumen terdiri atas kualitas produk, kualitas pelanggan, nilai/rasa emosional, harga, dan biaya.

Kepuasan konsumen merupakan rasa senang atau kecewa yang ditimbulkan ketika membandingkan antara harapan terhadap produk atau jasa dengan realita yang diterima oleh konsumen, sedangkan Tjiptono (2005) menunjukkan bahwa kepuasan pelanggan ialah suatu perkiraan pelanggan terhadap apa yang akan didapatkannya. Harapan pelanggan merupakan standar prediksi dalam menilai kepuasan. Harapan konsumen akan semakin meningkat dari waktu ke waktu seiring dengan semakin tumbuhnya informasi yang didapatkan konsumen dan semakin bertambahnya pengalaman yang didapatkan, sehingga hal itu akan berdampak pada perasaan puas yang dirasakan oleh konsumen (Gambar 2).

Salah satu faktor penentu untuk meningkatkan minat daya beli masyarakat dan mampu memberikan kepuasan pasca pembelian adalah lokasi. Salah satu kunci penting dalam menggapai kesuksesan bisnis ialah penentuan lokasi usaha (Kotler, 2008). Penentuan lokasi dalam bisnis merupakan salah satu strategi penting karena dapat mempengaruhi tercapainya visi dan tujuan bisnis. Dharmmesta dan Irawan (2003) menyatakan bahwa penentuan lokasi bisnis berkaitan dengan letak toko pengecer di daerah yang strategis, sehingga dapat meningkatkan pendapatan yang disebabkan oleh akses menuju toko usaha dapat dijangkau dengan mudah oleh konsumen. Heizer dan Render (2015) memberikan pendapat bahwa penentuan lokasi bisnis mampu menjadi pendorong pendapatan meningkat, karena lokasi sering menjadi pertimbangan dalam mendirikan dan membuat strategi bisnis perusahaan.

Di sisi lain, Munawaroh (2013) menyebutkan bahwa strategi tepat yang harus diperhatikan perusahaan sebelum mendirikan sebuah usaha adalah pemilihan lokasi usaha, baik lokasi untuk usaha ritel maupun lokasi pendirian kantor. Munawaroh (2013) melanjutkan bahwa hal-hal yang harus diperhatikan pada saat menentukan lokasi bisnis ritel atau jasa, yaitu kedekatan dengan konsumen, biaya transportasi, kualitas kehidupan, dan lokasi pesaing. Demikian pula, Tjiptono (2000) menambahkan bahwa penentuan lokasi bisnis sangat penting terutama untuk jalur keluar masuk barang, kemudahan konsumen menjangkau tempat usaha, visibilitas usaha karena lokasinya dapat dilihat 
dengan jelas dari tepi jalan, tempat parkir luas, aman, dan nyaman, serta menyediakan tempat yang cukup luas untuk melakukan ekspansi atau perluasan bisnis di kemudian hari.

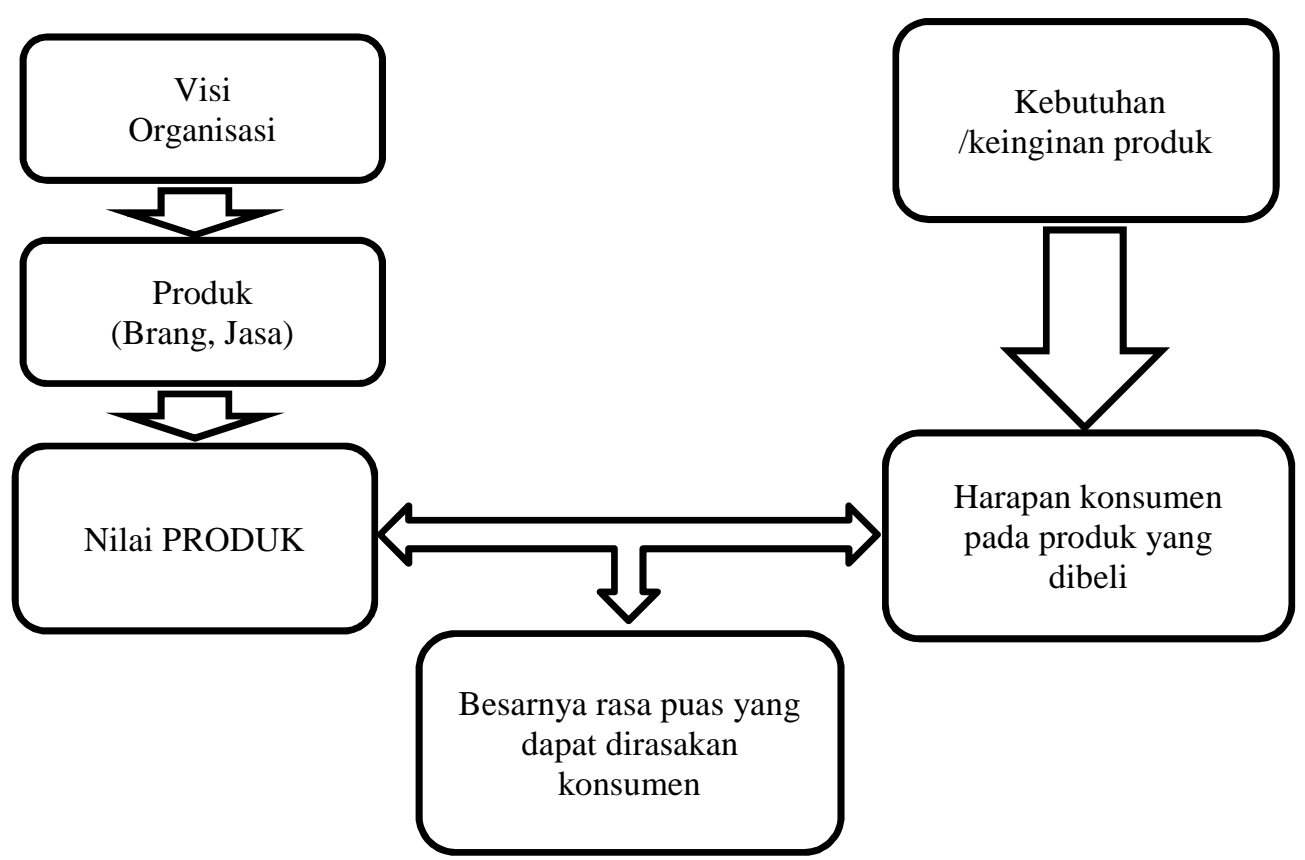

Sumber: Tjiptono (2005).

\section{Gambar 2. Alur Kepuasan Konsumen}

Setelah menentukan lokasi bisnis, faktor yang tidak kalah pentingnya dalam mempengaruhi keputusan dan kepuasan konsumen adalah pelayanan. Pelayanan yang excellent memerlukan ketekunan dan keuletan yang terdiri atas unsur kecepatan pelayanan, keramahan, dan kenyamanan bagi konsumen, agar mereka merasa puas dengan pelayanan yang diterima dan mereka menjadi konsumen loyal, serta tingkat pembelian mengalami peningkatan. Menurut Rangkuti dalam Sudarso (2016), pelayanan ialah memberikan jasa, baik tenaga atau pun pikiran yang melebihi tingkat kepentingan dan kebutuhan konsumen.

Pelayanan merupakan sikap (attitude) dalam melayani atau cara melayani konsumen, agar konsumen merasa dihormati, dihargai, dan mendapatkan kepuasan (Tjiptono, 2012). Hal tersebut diperkuat dengan penjelasan Kotler dan Amstrong (2004) yang menyebutkan bahwa pelayanan merupakan suatu kegiatan dengan memberikan sesuatu yang bermanfaat kepada pihak lain dan tidak berwujud, dan tidak adanya status perpindahan kepemilikan. Parasuraman et al. dalam Lupiyoadi (2001) menjelaskan bahwa pelayanan diartikan seberapa jauh perbedaan antara kenyataan dan harapaan konsumen terhadap pelayanan yang mereka terima. Lebih jauh, Lupiyoadi (2001) menyatakan dimensi untuk mengukur pelayanan adalah:

1. Keandalan adalah kemampuan yang dimiliki perusahaan dalam memberikan pelayanan akurat dan memuaskan konsumen. 
2. Keberwujudan adalah bukti fisik dalam layanan, yaitu fasilitas fisik, perlengkapan, atau peralatan yang digunakan, serta sarana komunikasi.

3. Daya tanggap adalah keinginan dan kemauan dalam membantu setiap konsumen dan memberikan layanan cepat, tepat, dan informasi jelas dan akurat.

4. Jaminan mencakup pengetahuan, skill, attitude, kesopanan, dapat dipercaya, bebas dari hal yang membahayakan, dan tidak ragu.

5. Empati berkaitan dengan cara-cara yang dapat memberikan kemudahan dalam menjalin komunikasi yang baik secara pribadi dan selalu memenuhi kebutuhan para konsumen.

Kotler dan Amstrong (2014) mendefinisikan bahwa produk merupakan sesuatu yang ditawarkan pada pasar agar dapat menarik perhatian, akuisisi, penggunaan, atau konsumsi yang dapat memuaskan keinginan atau kebutuhan konsumen. Selanjutnya, Tjiptono (2010) mendefinisikan produk ialah segala sesuatu yang bisa ditawarkan dan dijual ke pasar untuk mendapat perhatian, dimiliki, dipakai, dan dikonsumsi dengan tujuan bisa memberikan kepuasan sesuai keinginan dan kebutuhan, sedangkan Alma (2011) menjelaskan produk/barang merupakan suatu atribut baik berwujud maupun tidak berwujud, di dalamnya juga termasuk warna, harga, nama pabrik pembuat, nama toko penjual (pengecer), dan pabrik pelayan, serta pelayan pengecer, yang diterima pembeli demi untuk memuaskan keinginan konsumen.

Kotler (2005) memberikan arti bahwa kualitas produk mempunyai makna kondisi dinamis yang berhubungan langsung dengan produk, jasa, manusia, proses, dan lingkungan untuk memenuhi harapan konsumen. Mengukur kualitas produk dapat menggunakan indikator sebagai berikut (Putra \& Sunarti, 2010):

1. Performance (kinerja) berkaitan dengan karakteristik nilai pokok inti produk tersebut. Contohnya, bentuk dan kemasan yang baik dan menarik, disain-disain interior yang unik, nyaman, dan aman agar mampu menarik para konsumen.

2. Features (fitur) yaitu ciri khas yang tercantum dalam produk atau sesuatu yang istimewa dan harus selalu diubah atau dilakukan inovasi agar sesuai perkembangan jaman dan teknologi sebagai sebagai upaya untuk memuaskan pelanggan.

3. Durability (daya tahan) yaitu sebagian kecil produk bisa terjadi kerusakan atau mengalami kegagalan dalam pemakaian. Dalam hal ini, yang sering terjadi adalah konsumen akan merasakan kepuasan jika barang yang sudah dibeli tidak mengalami kerusakan.

4. Reliability (reliabilitas) ialah berkaitan dengan probablitas suatu produk yang gagal dalam menjalankan fungsi dan tugasnya.

5. Aesthetics (estetika) yaitu menciptakan produk harus memiliki estetika atau keindahan di dalamna agar mampu menarik minat konsumen.

6. Perceived quality (persepsi kualitas) yaitu persepsi konsumen terhadap kualitas, citra, dan reputasi produk atau merek yang menjadi tanggung jawab perusahaan.

7. Conformance to specifications (kesesuaian dengan spesifikasi) berkaitan dengan ketepatan antara kinerja dan kualitas produk menggunakan standar penilaian, serta sejauh mana perusahaan berupaya meningkatkan perubahan disain, bentuk, dan operasi demi memenuhi standar. 
Nilai emosional konsumen setelah melakukan pembelian juga berdampak kepada keputusan dan kepuasan konsumen. Nilai emosional adalah suatu value lebih yang didapatkan pada saat konsumen menggunakan produk atau jasa dari yang dihasilkan penjual dan hasil lain yang didapatkan yaitu nilai lebih dari produk tersebut. Bagozzi et al. dalam Wong dan Aspinwall (2004) menjelaskan emosional ialah membentuk dan menyiapkan mental yang muncul dari penilaian kognitif terhadap suatu kejadian atau pemikiran seorang melalui proses physiologi yang ditunjukkan melalui fisik, seperti bentuk wajah dan menimbulkan tindakan secara spesifik atau menguasai nilai emosional yang timbul dari sifat-sifat yang dimiliki orang yang mengalaminya, sedangkan Aisyah (2004) dalam Sudarso (2016) menjelaskan nilai emosional ialah perasaan atau tanggapan konsumen pada saat ingin melakukan keputusan pembelian pada dasarnya hanya merupakan sedikit perhatian untuk mencapai nilai kepuasan diri dari penggunaan produk. Menurut Tjiptono dalam Ridwan dan Palupiningdyah (2014), konsumen merasakan timbulnya perasaan yang positif (positive feeling) ketika membeli atau menggunakan produk, jika produk yang digunakan memberikan nilai emosional. Inilah yang membuat konsumen merasakan kepuasan pada produk yang digunakan.

Disain interior merupakan salah satu bagian strategi penting dalam menciptakan lingkungan dan suasana visual yang membuat konsumen merasa nyaman dan betah berada di dalam department store. Kramer (2008) dalam Kusumowidagdo dkk. (2013) menjelasakan fitur-fitur interior yang sangat penting untuk diperhatikan pengelola ritel ialah tata kelola ruang sewa-menyewa, aliran ruangan, kios, banyaknya lantai, tampilan depan toko, ukuran dan luas toko, basement, dinding interior, plumbing, pencahayaan, material pelapis lantai, dan kondisi sirkulasi udara. Keadaan emosi konsumen timbul disebabkan oleh suasana ruangan interior, sehingga mempengaruhi peningkatan atau penurunan pembelian. Disain interior yang baik dan tepat merupakan salah satu daya tarik konsumen untuk datang berkunjung. Saat ini, konsumen datang ke department store tidak murni untuk datang berbelanja saja, tetapi mereka juga ingin datang untuk bersantai dan menenangkan diri dan keluarganya.

Berbelanja merupakan suatu aktivitas yang berfungsi untuk melepaskan diri dari aktivitas dan rutinitas, mempelajari trend, dan model baru, kegiatan fisik, sensory stimulation (kegiatan cuci mata), bersosialisasi, dan berinteraksi dengan masyarakat. Penting diperhatikan bagi pengusaha ritel, disain interior bangunan dan ruangan yang menarik agar menjadi daya tarik konsumen, dan berdampak pada keinginan belanja konsumen meningkat. Semakin bagus disain, warna, dan bentuk gerainya, maka hal itu akan diikuti dengan semakin tinggi daya tarik bagi konsumen untuk berkunjung. Dikutip dalam Pancaningrum (2017), sebagaian besar masyarakat Indonesia pada saat berbelanja kebanyakan berorientasi pada keinginan untuk bersenang-senang, menikmati suasana, dan mendapatkan hiburan. Saat berbelanja, konsumen dapat menikmati visual marchandise, disain toko, dan atmosfer toko, maka kemungkinan akan terjadi pembelian impulsif. Menurut Ma'ruf dalam Pancaningrum (2017), unsur-unsur atmosfer dan ambience yang berhubungan dengan disain interior dan mampu mempengaruhi konsumen adalah:

\section{Visual}

Visual adalah hal-hal yang berkaitan dengan sesuatu yang dipandang seperti warna, cahaya, ukuran, dan bentuk. Warna dan cahaya dalam interior sangat penting dalam aspek visual, yaitu cahaya cerah yang terang benderang akan memberi dampak pada 
peningkatan energi. Tata letak lampu ruangan harus tepat dengan tujuan untuk memberikan efek kesejukan, kejelasan, dan keterangan bagi pengunjung dan pengguna lainnya.

\section{Tactile}

Tactile yaitu berbagai hal yang berkaitan dengan sentuhan tangan atau pun sentuhan kulit atau adanya sentuhan lembut yang dirasakan oleh kaki konsumen pada saat berkunjung ke gerai. Misalnya, pemakian karpet halus.

\section{Olfactory}

Olfactory berkaitan dengan daya hirup konsumen yang datang berkunjung, seperti tersedianya pengharum ruangan, bebauan scent dan frechness. Dengan tersedianya pengharum ruangan, maka suasana dan kesan diciptakan tersendiri dalam benak konsumen.

\section{Aural}

Aural berarti suara, yaitu kemampuan untuk menciptakan suasana nyaman dan damai bagi pengunjung dengan memberikan suara musik, volume dengan tempo musik yang santai, dan instrumen musik yang tenang agar suasana hati pengunjung tenang dan menikmati. Selain itu, nada musik yang lembut mampu membuat pengunjung gerai terpengaruh untuk datang kembali dan tetap tinggal di dalam gerai sambil melakukan pembelanjaan secara santai dibandingkan dengan suara musik yang keras.

Dari penjelasan teori dan permasalahan di atas, maka hipotesis yang dikemukakan di dalam penulisan artikel ini ialah:

1. Secara parsial, keputusan pembelian dan kepuasan konsumen Gardena Department Store \& Supermarket Yogyakarta dipengaruhi oleh lokasi, pelayanan, kualitas produk, nilai emosional, dan disain interior.

2. Secara simultan, keputusan pembelian dan kepuasan konsumen Gardena Department Store \& Supermarket Yogyakarta dipengaruhi oleh lokasi, pelayanan, kualitas produk, nilai emosional, dan disain interior.

3. Ada pengaruh keputusan pembelian terhadap kepuasan konsumen Gardena Department Store \& Supermarket Yogyakarta.

Hipotesis yang diajukan dalam penelitian ini digambarkan dalam model rerangka penelitian berikut ini (Gambar 2). 


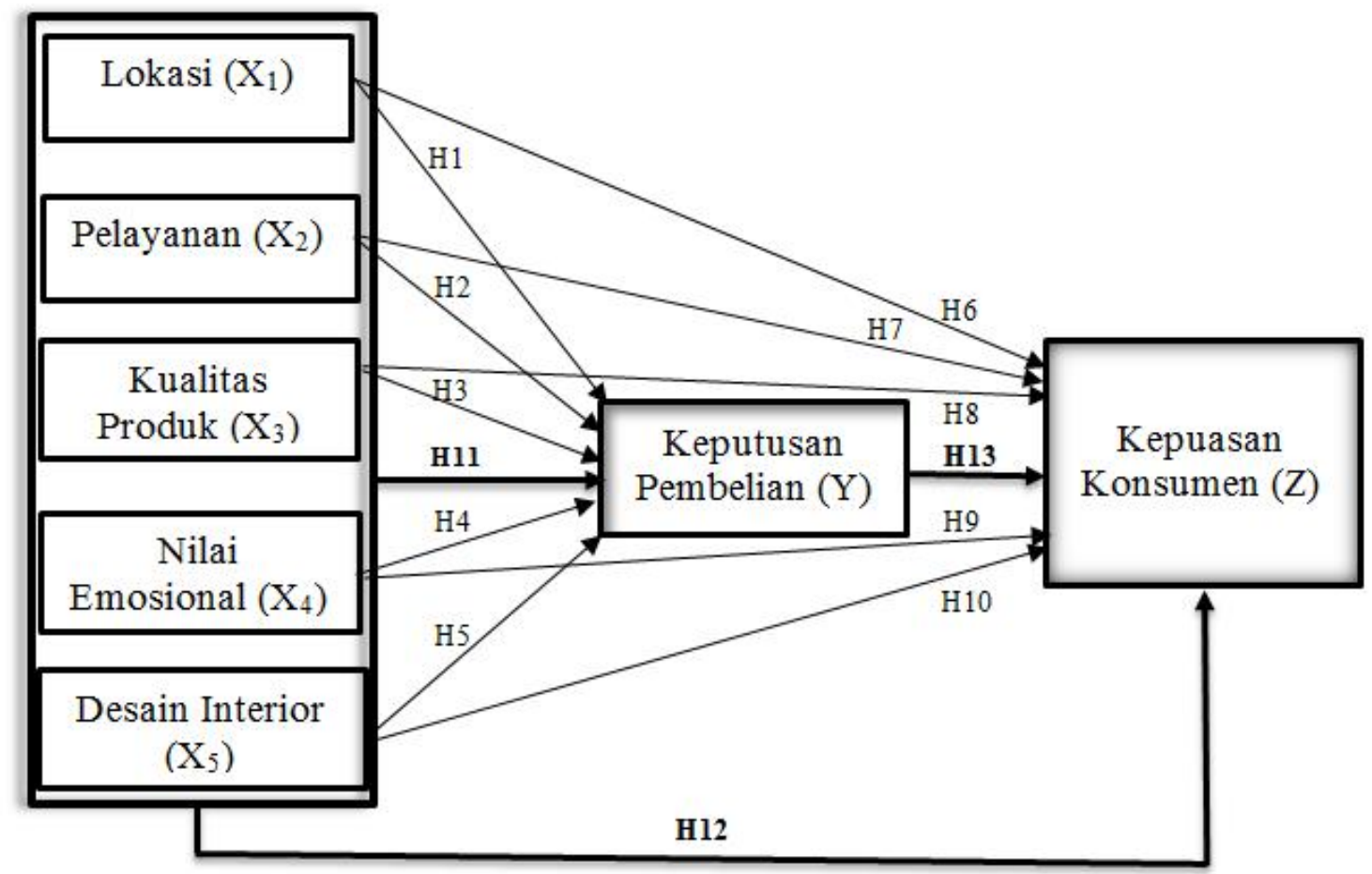

Gambar 2. Model Penelitian

\section{METODE PENELITIAN}

Disain penelitian ini menggunakan pendekatan kuantitatif berupa beberapa butir pertanyaan yang diajukan ke responden yang kemudian diubah menjadi data kualitatif, yaitu jenis penelitian yang menekankan pada analisis data diskriptif. Tujuan pendekatan eksplanatif ini untuk menjelaskan hubungan kausalitas antara variabel dependen, yaitu keputusan pembelian (Y) dan kepuasan konsumen (Z) dengan variabel-variabel independen yang terdiri atas lokasi $\left(\mathrm{X}_{1}\right)$, pelayanan $\left(\mathrm{X}_{2}\right)$, kualitas produk $\left(\mathrm{X}_{3}\right)$, nilai emosional $\left(\mathrm{X}_{4}\right)$, dan disain interior $\left(\mathrm{X}_{5}\right)$. Dalam pengujian hipotesis, peneliti mengumpulkan data dengan cara dokumentasi dan kuesioner.

Dalam penelitian ini, populasi dan sampel penelitian yang digunakan ialah customer yang berbelanja kebutuhan sehari-hari di Gardena Department Store \& Supermarket di Jalan Urip Sumoharjo No. 40 Yogyakarta. Populasi adalah wilayah generalisasi yang terdiri atas obyek/subyek yang mempunyai kualitas dan karakteristik tertentu yang ditetapkan oleh peneliti untuk dipelajari dan kemudian ditarik kesimpulannya (Sugiyono, 2008). Sampel adalah bagian dari jumlah karakteristik yang dimiliki oleh populasi (Sugiyono, 2008), sehingga jumlah sampel yang diambil oleh peneliti sebanyak 100 sampel dengan menggunakan skala Likert. Skala Likert adalah skala yang digunakan untuk mengukur pendapat, sikap, dan persepsi seseorang atau sekelompok orang tentang suatu fenomena sosial (Sugiyono, 2008). Dalam penilaian ini, skala Likert setiap jawaban diberikan skor nilai, yaitu: Sangat Setuju skor 5, Setuju skor 4, Ragu-ragu skor 3, Tidak setuju skor 2, Sangat tidak setuju skor 1. Sampel yang diambil adalah konsumen yang datang berbelanja ke Gardena Department Store \& Supermarket pada bulan Mei-Juni 2018 untuk berbelanja kebutuhan sehari-hari pada saat puasa dan menjelang lebaran atahun 2018. Metode pengambilan sampel mengguna-kan purposive 
sampling, yaitu teknik penentuan sampel dengan pertimbangan tertentu (Sugiyono, 2008).

Penelitian ini menggunakan dua teknik pengumpulan data, yaitu data primer dan sekunder. Data primer dikumpulkan menggunakan kuesioner. Kuesioner merupakan teknik pengumpulan data yang dilakukan dengan cara memberi seperangkat pertanyaan atau pernyataan tertulis kepada responden untuk dijawab (Sugiyono, 2008), sedangkan data sekunder didapatkan dari buku-buku, skripsi, tesis, dan jurnal. Untuk menguji sah atau validnya item-item pertanyaan dalam kuesioner digunakan uji validitas dan reliabilitas. Sugiyono (2008) menyatakan bahwa uji validitas dipakai untuk mengetahui tingkat kevalidan dari instrumen kuesioner yang digunakan dalam pengumpulan data. Uji validitas dipakai dengan cara menghitung korelasi Pearson Product Moment ( $\mathrm{r}_{\text {hitung }}>$ $\left.\mathrm{r}_{\text {tabel }}\right)$. Berdasarkan perhitungan, setiap butir pernyataan diperoleh nilai $\mathrm{r}_{\text {hitung }}$ lebih besar dari $\mathrm{r}_{\text {tabel }}\left(\mathrm{r}_{\text {hitung }}\right.$ product moment) yang menunjukkan angka sebesar 0,195 maka butirbutir pertanyaan dinyatakan valid. Arikunto (2006) menyebutkan bahwa uji reliabilitas didapatkan dengan melihat nilai dari Cronbach Alpha, yaitu instrumen penelitian dapat dinyakatan reliabel, apabila setiap variabel memiliki nilai koefisien atau alpha sebesar 0,6 atau lebih. Uji reliabilitas menggunakan perhitungan Cronbach Alpha menunjukkan hasil bahwa nilai alpha semua variabel lebih tinggi dari nilai standar Cronbach Alpha 0,6 maka semua variabel penelitian dinyatakan andal.

Metode penelitian menggunakan regresi linier berganda dipakai untuk membuktikan jawaban hipotesis naik-turunnya dan untuk mengetahui seberapa besar pengaruh antara lokasi $\left(\mathrm{X}_{1}\right)$, pelayanan $\left(\mathrm{X}_{2}\right)$, kualitas produk $\left(\mathrm{X}_{3}\right)$, nilai emosional $\left(\mathrm{X}_{4}\right)$, dan disain interior $\left(\mathrm{X}_{5}\right)$ terhadap keputusan pembelian $(\mathrm{Y})$ dan kepuasan konsumen $(\mathrm{Z})$, serta menganalisis pengaruh keputusan pembelian terhadap kepuasan konsumen. Persamaan regresi penelitian ini dapat digambarkan sebagai berikut:

$$
\begin{aligned}
& Y=\alpha+b_{1} X_{1}+b_{2} X_{2}+b_{3} X_{3}+b_{4} X_{4}+b_{5} X_{5} \\
& Z=\alpha+b_{1} X_{1}+b_{2} X_{2}+b_{3} X_{3}+b_{4} X_{4}+b_{5} X_{5} \\
& Z=\alpha+b Y \ldots \ldots \ldots \ldots \ldots \ldots \ldots \ldots \ldots \ldots \ldots \ldots \ldots \ldots \ldots \ldots \ldots \ldots \ldots \ldots \ldots \ldots \ldots \ldots \ldots \ldots \ldots \ldots \ldots \ldots
\end{aligned}
$$

Pengujian hipotesis dalam penelitian ini secara parsial menggunakan uji t dan untuk menguji kebenaran hipotesis secara simultan menggunakan uji F. Priyatno (2009) mendefinisikan uji $\mathrm{F}$ digunakan untuk mengetahui pengaruh variabel independen secara simultan terhadap variabel dependen, apakah pengaruhnya signifikan atau tidak dengan taraf signifikansi 0,05 (df1=k-1, df2=n-k), sedangkan uji t digunakan untuk mengetahui pengaruh variabel independen secara parsial terhadap variabel dependen $(\mathrm{df}=\mathrm{n}-\mathrm{k}-1)$.

\section{HASIL DAN PEMBAHASAN}

Hasil pengolahan data kuesioner yang dilakukan pada jawaban konsumen Gardena Department Store \& Supermarket Yogyakarta sebanyak 100 responden atau semua. Setelah dilakukan analisis diperoleh hasil sebagai berikut:

1. Hasil klasifikasi responden berdasarkan jenis kelamin didominasi oleh responden wanita sebanyak 76 orang, Berdasarkan usia tingkat usia reponden terbanyak yaitu usia 30-39 tahun sebanyak 48 orang, tingkat pendidikan terakhir terbanyak adalah Sarjana yaitu sebanyak 47 orang, dan berdasarkan klasifikasi dibidang pekerjaan yang paling banyak ialah pegawai swasta yaitu sebanyak 39 orang. 
2. Berdasarkan hasil pengujian validitas, setelah menghitung dan mengolah data dari setiap total/jumlah butir pertanyaan variabel secara keseluruhan menunjukkan nilai $\left(r_{\text {hitung }}>r_{\text {tabel }}\right)$. Angka $r_{\text {tabel }}$ dengan nilai signifikansi sebesar $5 \%$ dan df $=\mathrm{N}=100-2=98$ menunjukkan nilai $r_{\text {tabel }}$ sebesar 0,195. Dari hasil perhitungan inilah membuktikan bahwa nilai ( $\mathrm{r}_{\text {hitung }}>\mathrm{r}_{\text {tabel }}$ ) maka semua butir-butir pertanyaan yang digunakan dalam variabel bebas dan variabel terikat dapat diputuskan semua valid. Sedangkan pada uji reliabilitas cara yang digunakan adalah dengan melihat nilai koefisien dengan Alpha Cronbach's dengan nilai 0.6. Dari hasil pengolahan data dapat didapatkan bahwa semua variabel yang digunakan dalam penelitian ini mendapatkan hasil nilai Cronbach's Alpha>0,6 maka instrumen dalam penelitian ini handal.

3. Hasil uji variabel lokasi, pelayanan, kualitas produk, nilai emosional dan disain interior terhadap keputusan pembelian.

\section{a. Uji Regresi Linier Berganda}

Persamaan regresi linier berganda dengan melihat nilai beta unstandardized coefficients sebagai berikut:

$$
Y=5,502+0,337 X_{1}+0,192 X_{2}+0,288 X_{3}+0,179 X_{4}-188 X_{5}
$$

Tabel 1. Keputuan Pembelian Dipengaruhi Lokasi, Pelayanan, Kualitas Produk, Nilai Emosional, dan Disain Interior

\begin{tabular}{|c|c|c|c|c|}
\hline \multirow[t]{2}{*}{ 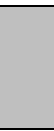 } & \multirow[t]{2}{*}{ Model } & \multicolumn{2}{|c|}{ Unstandardized Coefficients } & \multirow{2}{*}{$\begin{array}{c}\text { Standardized } \\
\text { Coefficients } \\
\text { Beta } \\
\end{array}$} \\
\hline & & B & Std. Error & \\
\hline \multirow[t]{6}{*}{1} & (Constant) & 5,502 & 3,443 & \\
\hline & Lokasi $\mathrm{X}_{1}$ & ,337 &, 114 & 273 \\
\hline & Pelayanan $\mathrm{X}_{2}$ &, 193 & 094 & 193 \\
\hline & Kualitas Produk $\mathrm{X}_{3}$ & ,288 &, 125 & 212 \\
\hline & Nilai Emosional $\mathrm{X}_{4}$ & , 179 & ,112 &, 152 \\
\hline & Disain Interior $\mathrm{X}_{5}$ &,- 188 &, 095 &,- 180 \\
\hline
\end{tabular}

Dependent Variable: Keputusan Pembelian (Y)

Sumber: Hasil olahan data, 2018.

Berdasarkan Tabel 1 di atas, nilai konstanta menunjukkan angka sebesar 5,502 yang berarti bahwa apabila variabel independen lokasi, pelayanan, kualitas produk, nilai emosional, dan disain interior dalam keadaan tetap, maka keputusan pembelian sebesar 5,502. Selanjutnya, variabel lokasi, pelayanan, kualitas produk, dan nilai emosional ditingkatkan, maka berdampak pada meningkatnya keputusan pembelian konsumen Gardena Department Store \& Supermarket Yogyakarta, sedangkan apabila disain interior diturunkan, maka keputusan pembelian mengalami penurunan.

Persamaan regresi dengan nilai beta unstandardized coefficients:

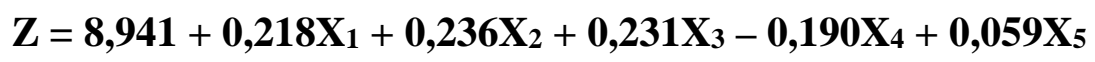


Tabel 2. Kepuasan Konsumen Dipengaruhi Lokasi, Pelayanan, Kualitas Produk, Nilai Emosional, dan Disain Interior

\begin{tabular}{|c|c|c|c|c|}
\hline & \multirow[t]{2}{*}{ Model } & \multicolumn{2}{|c|}{ Unstandardized Coefficients } & \multirow{2}{*}{$\begin{array}{c}\begin{array}{c}\text { Standardized } \\
\text { Coefficients }\end{array} \\
\text { Beta } \\
\end{array}$} \\
\hline & & B & Std. Error & \\
\hline \multirow[t]{6}{*}{1} & $($ Constant $)$ & 8,941 & 3,659 & \\
\hline & Lokasi $\mathrm{X}_{1}$ & ,218 &, 111 & , 189 \\
\hline & Pelayanan $\mathrm{X}_{2}$ & ,236 & ,097 & ,236 \\
\hline & Kualitas Produk $\mathrm{X}_{3}$ & ,231 &, 115 & , 197 \\
\hline & Nilai Emosional $\mathrm{X}_{4}$ &,- 190 &, 100 &,- 182 \\
\hline & Disain Interior $\mathrm{X}_{5}$ & ,059 & ,130 &, 043 \\
\hline
\end{tabular}

Dependent Variable: Kepuasan Konsumen (Z)

Sumber: Hasil olahan data, 2018.

Berdasarkan Tabel 2 di atas, nilai konstanta diperoleh sebesar 8,941 artinya apabila variabel independen (lokasi, pelayanan, kualitas produk, nilai emosional, dan disain interior) dalam keadaan tetap, maka kepuasan konsumen mencapai 8,5941. Selanjutnya, variabel lokasi, pelayanan, kualitas produk, dan disain interior ditingkatkan sebesar 1 satuan, maka akan diikuti oleh kepuasan konsumen Gardena Department Store \& Supermarket Yogyakarta mengalami peningkatan, sedangkan nilai emosional diturunkan akan diikuti oleh kepuasan konsumen mengalami penurunan.

Tabel 3. Hasil Uji Regresi Keputusan Pembelian terhadap Kepuasan Konsumen

\begin{tabular}{rlrrr}
\hline \multirow{2}{*}{ Model } & & \multicolumn{1}{c}{ Unstandardized Coefficients } & \multicolumn{1}{c}{$\begin{array}{c}\text { Standardized } \\
\text { Coefficients }\end{array}$} \\
\cline { 3 - 5 } & & \multicolumn{1}{c}{ B } & Std. Error & \multicolumn{1}{c}{ Beta } \\
\hline \multirow{2}{*}{1} & (Constant) & 11,834 & 1,767 & \\
\cline { 2 - 5 } & Keputusan Pembelian $(\mathrm{Y})$ &, 359 &, 119 &, 291 \\
\hline
\end{tabular}

Dependent Variable: Kepuasan Konsumen (Z)

Sumber: Hasil olahan data, 2018.

Persamaan regresi nilai beta unstandardized coefficients:

$$
\mathrm{Z}=11,834+0,359 \mathrm{Y}
$$

Berdasarkan Tabel 3 diatas didapatkan nilai konstanta sebesar 11,834 artinya jika dalam hal ini keputusan pembelian dalam keadaan tetap tidak ada perubahan maka besarnya kepuasan konsumen 11,834. Selanjutnya keputusan pembelian ditingkan sebesar 1 satuan, maka selajutnya kepuasan konsumen mengalami peningkatan. Dari hasil penelitian ini didapatkan dan membuktikan disaat keputusan pembelian mengalami peningkatan maka kepuasan konsumen juga mengalami peningkatan, disaat konsumen puas maka berdampak pada adanya peningkatan penjualan pada Gardena Department Store \& Supermarket Yogyakarta.

\section{b. Hasil Pengujian Hipotesa Penelitian}

\section{1) Hasil Uji Parsial (Uji t)}


Tabel 4. Keputusan Pembelian Dipengaruhi Lokasi, Pelayanan, Kualitas Produk, Nilai Emosional, \& Disain Interior

\begin{tabular}{llll}
\hline \multicolumn{2}{c}{ Model } & \multicolumn{1}{c}{ t } & \multicolumn{2}{c}{ Sig. } \\
\hline 1 & (Constant $)$ & 1,598 &, 113 \\
\cline { 2 - 4 } & Lokasi $\mathrm{X}_{1}$ & 2,963 &, 004 \\
\cline { 2 - 4 } & Pelayanan $\mathrm{X}_{2}$ & 2,060 &, 042 \\
\cline { 2 - 4 } & Kualitas Produk $\mathrm{X}_{3}$ & 2,297 &, 024 \\
\cline { 2 - 4 } & Nilai Emosional $\mathrm{X}_{4}$ & 1,608 &, 111 \\
\cline { 2 - 4 } & Disain Interior $\mathrm{X}_{5}$ & $-1,976$ &, 051 \\
\hline
\end{tabular}

Dependent Variable: Keputusan Pembelian (Y)

Sumber: Hasil olahan data, 2018.

Hasil pada Tabel 4 di atas dengan taraf signifikansi 0,05 menunjukkan uji parsial yang digunakan untuk membuktikan pengaruh variabel bebas terhadap variabel terikat dengan rumus $\mathrm{df}=\mathrm{n}-\mathrm{k}-1$ yaitu $(100-7-1=92)$, maka didapatkan nilai $t_{\text {tabel }}=1,986$. Maka, terbukti bahwa variabel lokasi, pelayanan, dan kualitas produk berpengaruh secara positif dan signifikan terhadap keputusan pembelian konsumen Gardena Department Store \& Supermarket Yogyakarta karena mempunyai nilai thitung lebih besar dari $\mathrm{t}_{\text {tabel. }}$.

Hasil penelitian ini sesuai dengan penelitian Ghazali (2010), yaitu variabel lokasi dan layanan mempunyai pengaruh pada keputusan pembelian warung internet XYZ. Hal ini juga sejalan dengan hasil penelitian Iswayanti (2010) yaitu kualitas produk dan layanan berpengaruh positif pada keputusan pembelian Soto Angkring Mas Boed Semarang. Hasil penelitian Mujiroh (2005) juga membuktikan variabel produk, lokasi, dan layanan mempunyai pengaruh pada keputusan pembelian di pasar swalayan Indo Rizky Purbalingga,. Dari hasil penelitian ini didapatkan nilai emosional dan disain interior tidak berpengaruh pada keputusan pembelian konsumen Gardena Department Store \& Supermarket Yogyakarta dikarenakan nilai $t_{\text {hitung }}<\mathrm{t}_{\text {tabel }}$.

Hasil penelitian ini bertentangan dengan hasil penelitian Siregar (2012) yang mendapatkan bahwa nilai emosional berpengaruh positif dan signifikan pada keputusan pembelian pada Jittlada Thai Cuisine Cambridge Medan. Penelitian Setianingsih dan Nurhadi (2016) menunjuk-kan disain interior (suasana toko) berpengaruh positif pada keputusan pembelian. Hasil penelitian ini menunjukkan bahwa konsumen Gardena Department Store \& Supermarket Yogyakarta dalam memutuskan pembelian lebih mengutamakan lokasi yang berada di tengah kota, pelayanan yang cepat, ramah, dan sopan, serta kualitas produk yang baik, sedangkan nilai emosional dan disain interior bangunan tidak mempeng-aruhi keputusan pembelian mereka. 
Tabel 5. Kepuasan Konsumen Dipengaruhi Lokasi, Pelayanan, Kualitas Produk, Nilai Emosional, dan Disain Interior

\begin{tabular}{llrr}
\multicolumn{1}{c}{ Model } & \multicolumn{2}{c}{ t } & \multicolumn{2}{c}{ Sig. } \\
\hline \multirow{2}{*}{1} & $($ Constant $)$ & 2,443 &, 016 \\
\cline { 2 - 4 } & Lokasi $\left(\mathrm{X}_{1}\right)$ & 1,970 &, 052 \\
\cline { 2 - 4 } & Pelayanan $\left(\mathrm{X}_{2}\right)$ & 2,421 &, 017 \\
\cline { 2 - 4 } & Kualitas Produk $\left(\mathrm{X}_{3}\right)$ & 2,017 &, 047 \\
\cline { 2 - 4 } & Nilai Emosional $\left(\mathrm{X}_{4}\right)$ & $-1,913$ &, 059 \\
\cline { 2 - 4 } & Disain Interior $\left(\mathrm{X}_{5}\right)$ &, 452 &, 652 \\
\hline
\end{tabular}

Dependent Variable: Kepuasan Konsumen (Z)

Sumber: Hasil olahan data, 2018.

Hasil pada Tabel 5 membuktikan secara parsial bahwa variabel lokasi, pelayanan, dan kualitas produk mempunyai pengaruh positif dan signifikan pada kepuasan konsumen $(\mathrm{Z})$. Hal tersebut dibuktikan dengan nilai $\mathrm{t}_{\text {hitung }}>$ $\mathrm{t}_{\text {tabel }}$ sebesar 1,986. Hasil penelitian ini sesuai dengan penelitian Rahman (2013) bahwa variabel kualitas pelayanan dan lokasi mempunyai pengaruh pada kepuasan konsumen pada pemancingan Ngrembel Asri Gunungpati, Semarang. Selanjutnya, penelitian Hilaliyah dkk. (2017) memperoleh hasil layanan dan kualitas produk mempunyai pengaruh yang signifikan pada kepuasan pelanggan Kafe Ria Djenaka, Malang.

Variabel nilai emosional $\left(\mathrm{X}_{4}\right)$ dan disain interior $\left(\mathrm{X}_{5}\right)$ tidak mempunyai pengaruh pada kepuasan konsumen $(\mathrm{Z})$ karena nilai $\mathrm{t}_{\text {hitung }}<\mathrm{t}_{\text {tabel }}$. Hasil penelitian ini berbanding terbalik dari penelitian yang dilakukan Saputri dkk. (2017) yangmendapatkan hasil bahwa nilai emosional secara parsial mempunyai pengaruh signifikan pada kepuasan konsumen McDonald di Sidoarjo. Sejalan dengan hasil penelitian tersebut, Anggraeni dan Hermiati (2013) menyatakan bahwa kondisi interior berpengaruh positif terhadap minat beli ulang konsumen Black House Cafe.

Dari hasil penelitin terdahulu diatas membuktikan bahwa nilai emosional yang didapatkan pelanggan setelah menggunakan produk atau jasa dapat memberi nilai tambah uang ditimbulkan dan dirasakan. Sedangkan disain interior (suasana toko) mampu menciptakan suasana dan keadaan lingkungan toko pembelian yang dapat menimbulkan efek emosional yang berpengaruh pada keputusan konsumen dalam berberbelanja terutama dalam lingkungan fisik. Akan tetapi pada penelitian ini membuktikan bahwa kepuasan konsumen pada Gardena Department Store \& Supermarket tidak dipengaruhi oleh disain interior dan nilai emosional, tetapi lebih mengutamakan pelayanan, lokasi dan kualitas produk, elemen-elemen inilah yang mampu meningkatkan pembelian konsumen. 
Tabel 6. Pengaruh Kepuasan Konsumen Terhadap Keputusan Pembelian

\begin{tabular}{|c|c|c|c|}
\hline & Model & $\mathbf{t}$ & Sig. \\
\hline \multirow[t]{2}{*}{1} & (Constant) & 6,696 &, 000 \\
\hline & Keputusan Pembelian & 3,006 & ,003 \\
\hline
\end{tabular}

Dependent Variable: Kepuasan Konsumen

Sumber: Hasil olahan data, 2018.

Hasil pada Tabel 6 membuktikan bahwa keputusan pembelian mempunyai pengaruh positif dan signifikan pada kepuasan konsumen Gardena Department Store \& Supermarket Yogyakarta. Hal itu terbukti dengan nilai $t_{\text {hitung }}(3,006)>t_{\text {tabel }}(1,986)$ dan nilai signifikan $0,003<0,05$. Dengan adanya pengaruh keputusan pembelian terhadap kepuasan konsumen, maka hal itu berdampak pada peningkatan pembelian. Hasil penelitian ini sama dengan penelitian Hidayat (2015) yang menyatakan bahwa kepuasan konsumen dalam hal ini mahasiswa Universitas Telkom berpengaruh signifikan pada keputusan pembelian konsumen pada produk lampu Phillip. Hasil tersebut diperkuat oleh penelitian yang dilakukan oleh Hartono dan Wahyono (2015) yang menyebutkan bahwa keputusan pembelian berpengaruh langsung terhadap kepuasan konsumen.

\section{2) Hasil Uji Simultan (Uji F)}

Uji simultan dilakukan untuk mengetahui ada tidaknya pengaruh variabel independent secara simultan terhadap variabel dependen dalam hal ini keputusan pembelian (Y) dan kepuasan konsumen (Z). Pengujian ini dilakukan dengan melihat nilai $F_{\text {hitung }}$ dengan $F_{\text {tabel }}$ dengan tigkat kepercayaan 95\% $(\alpha=0,05)$ dengan derajat kebebasan df1 $\mathrm{k}-1=7-1=6$ dan $\mathrm{df} 2=(\mathrm{n}-\mathrm{k})=100-7=93$ maka diperoleh nilai $\mathrm{F}_{\text {tabel }}$ sebesar $=2,20$.

Tabel 7. Keputusan Pembelian Dipengaruhi Lokasi, Pelayanan, Kualitas Produk, Nilai Emosional, dan Desain Interior

\begin{tabular}{lllrrrrr}
\hline \multicolumn{8}{c}{ ANOVA $^{\text {a }}$} \\
Model & Sum of Squares & df & Mean Square & \multicolumn{1}{c}{ F } & \multicolumn{1}{c}{ Sig. } \\
\hline \multirow{3}{*}{1} & Regression & 240,649 & 5 & 48,130 & 5,354 &, $000^{\text {b }}$ \\
\cline { 2 - 8 } & Residual & 844,991 & 94 & 8,989 & & \\
\cline { 2 - 8 } & Total & 1085,640 & 99 & & & \\
\hline
\end{tabular}

a. Dependent Variable: Keputusan Pembelian (Y)

Sumber: Hasil olahan data, 2018.

Hasil pada Ttabel 7 di atas menunjukkan nilai $F_{\text {hitung }}(5,354)>F_{\text {tabel }}(2,20)$ dengan nilai signifikasi $0,000<0,05$. Artinya, hasil ini membuktikan secara simultan bahwa variabel lokasi, pelayanan, kualitas produk, nilai emosional, dan disain interior memiliki pengaruh positif dan signifikan pada kepuasan konsumen (Y). 


\section{Tabel 8. Kepuasan Konsumen Dipengaruhi Lokasi, Pelayanan, Kualitas Produk, Nilai Emosional dan Desai Interior terhadap Kepuasan Konsumen}

\begin{tabular}{|c|c|c|c|c|c|c|}
\hline \multicolumn{7}{|c|}{ ANOVA $^{a}$} \\
\hline & Model & Sum of Squares & $d f$ & Mean Square & $\mathbf{F}$ & Sig. \\
\hline \multirow{3}{*}{1} & Regression & 163,284 & 5 & 32,657 & 3,328 &, $008^{\mathrm{b}}$ \\
\hline & Residual & 922,356 & 94 & 9,812 & & \\
\hline & Total & 1085,640 & 99 & & & \\
\hline
\end{tabular}

a. Dependent Variable: Kepuasan Konsumen (Y)

b. Predictors: (Constant), $\mathrm{X}_{1}, \mathrm{X}_{2}, \mathrm{X}_{3}, \mathrm{X}_{4}, \mathrm{X}_{5}$

Sumber: Hasil Olahan Data, 2018.

Berdasarkan tabel 8 diatas didapatkan nilai $F_{\text {hitung }} 3,328>F_{\text {tabel }} 2,20$ dengan nilai sig. $0,008<0,05$. Artinya terbukti secara simultan lokasi, pelayanan, kualitas produk, nilai emosional dan disain interior mempunyai pengaruh yang positif dan signifikan pada kepuasan konsumen (Y).

\section{KESIMPULAN DAN SARAN}

Dari hasil analisis data dan pembahasan, klasifikasi responden berdasarkan jenis kelamin didominasi oleh responden wanita sebanyak 76 orang, tingkat usia reponden terbanyak, yaitu usia antara 30-39 tahun sebanyak 48 orang, tingkat pendidikan terakhir terbanyak adalah sarjana sebanyak 47 orang, dan berdasarkan jenis pekerjaan adalah pegawai swasta sebanyak 39 orang. Hasil penelitian ini membuktikan bahwa jika keputusan pembelian mengalami peningkatan, maka kepuasan konsumen juga akan meningkat. Ketika konsumen merasa puas akan berdampak pada peningkatan penjualan pada Gardena Department Store \& Supermarket Yogyakarta. Dari pengujian secara parsial (uji t) terbukti bahwa lokasi, pelayanan, dan kualitas produk mempunyai pengaruh positif dan signifikan pada keputusan pembelian (Y) dan kepuasan konsumen (Z), sedangkan nilai emosional dan disain interior tidak mempunyai pengaruh pada keputusan pembelian (Y) dan kepuasan konsumen (Z), karena nilai $t_{\text {hitung }}<\mathrm{t}_{\text {tabel. }}$. Selanjutnya, variabel keputusan pembelian mempunyai pengaruh positif dan signifikan pada kepuasan konsumen. Secara simultan, lokasi, pelayanan, kualitas produk, nilai emosional dan disain interior mempunyai pengaruh positif dan signifikan terhadap keputusan pembelian (Y) dan kepuasan konsumen (Z).

Saran bagi manajemen Gardena Department Store \& Supermarket Yogyakarta adalah tetap mempertahankan elemen-elemen yang mampu mempengaruhi keputusan pembelian dan kepuasan konsumen berdasarkan hasil penelitian ini, yaitu pelayanan yang cepat, ramah, dan sopan, kualitas produk, dan lokasi dalam hal ini berkaitan dengan tempat parkir agar lebih diperhatikan untuk menghindari kemacetan lalu lintas. Untuk nilai emosional dan disain interior, sebaiknya manajemen tetap perlu memberikan nilainilai dan disain yang baru agar konsumen merasa betah. Keterbatasan dalam penelitian ini adalah responden yang terburu-buru pada saat mengisi kuesioner, adanya keterbatasan waktu dan biaya penelitian, jumlah responden terbatas 100 orang, dan variabel-variabel yang terbatas jumlahnya, sehingga untuk penelitian selanjutnya penulis menyarankan agar menambah jumlah responden dan waktu pengambilan sampel agak diperpanjang. 


\section{DAFTAR REFERENSI}

Alma (2011). Manajemen Pemasaran dan Pemasaran Jasa. Bandung: Alfabeta.

Arikunto. (2006). Metode Penelitian Kualitatif. Jakarta:Bumi Aksara.

Assauri, S. (2004). Manajemen Pemasaran Dasar Konsep dan Strategi. Jakarta: Raja Grafindo Persada.

Dharmmesta, B.S. \& Handoko, H. (2000). Manajemen Pemasaran, Analisa Perilaku Konsumen. Yogyakarta: BPFE.

Gardenamagelang (2011). Sejarah Berdirinya Gardena. Retrieved Mei 10, 2018, from http://gardenamagelang.blogspot.com/2011/04/sejarah-berdirinya-gardena.html.

Ghazali (2010). Analisis Lokasi, Promosi dan Layanan Terhadap Keputusan Pembelian pada Warnet XYZ. Universitas Diponegoro. Retrieved from http://eprints.undip. ac.id/26495.

Gudegnet (2016). Gardena Department Store \& Supermarket Yogyakarta. Retrieved Mei 10, 2018, from https://gudeg.net/direktori/427/gardena-department-store-\&supermarket-yogyakarta.html.

Hartono \& Wahyono (2015). Analisis Citra Merek dan Kualitas Terhadap Kepuasan Pelanggan Dengan Keputusan Membeli Variabel Intervening. Management Analysis Journal, 4(2). 153-162. https://doi.org/10.15294/maj.v4i2.7824.

Heizer \& Render. (2015). Manajemen Operasi: Keberlangsungan dan Rantai Pasokan. Edisi Sebelas. Diterjemahkan oleh: Hirson Kurnia, R, dkk. Jakarta: Salemba Empat.

Hidayat (2015). Pengaruh Kepuasan Pelanggan terhadap Keputusan Membelian Lampu Philips (Studi Kasus pada Mahasiswa Telkom University). Jurnal Ecodemica: Jurnal Ekonomi, Manajemen, dan Bisnis, 3(1). 305-310. https://doi.org/10.31311/ jeco.v3i1.57.

Hilaliyah, S.A., Djawahir, A.H., \& Susilowati, C. (2017). Pengaruh Kualitas Layanan dan Kualitas Produk Yang di Moderasi oleh Suasana terhadap Kepuasan Pelanggan (Studi pada Mahasiswa Pelanggan Kafe Ria Djenaka Malang). Jurnal Bisnis dan Manajemen, 4(2). 172-187.

Irawan (2009). 10 Prinsip Kepuasan Pelanggan. Jakarta: Media Komputindo.

Iswayanti (2010). Pengaruh Kualitas Produk, Layanan, Harga, dan Tempat Terhadap Keputusan Pembelian pada Rumah Makan "Soto Angkring Mas Boed Semarang. Universitas Diponegoro. Retrieved from http://eprints.undip.ac.id/23470.

Kumparan (2017). Tahun 2025 RI Akan Kuasai 52\% Pasar E-Commerce di Asia Tenggara. Retrieved Mei 10, 2018, from https://kumparan.com/@kumparannews/ tahun-2025-ri-akan-kuasai-52-pasar-e-commerce-di-asia-tenggara.

Kusumowidagdo, A., Sachari, A., \& Widodo, P. (2013). Pengaruh Atmosfer Pusat Belanja Pada Shopping Value. Jurnal Siasat Bisnis, 17(1). 28-44.

Kotler, P. \& Armstrong, G. (2014). Dasar-Dasar Pemasaran, Edisi 9, Jilid Pertama, Terjemahan: Alexander S. Jakarta: Indeks.

Kotler, P. (2008). Manajemen Pemasaran. Edisi Dua Belas. Jilid Dua. Jakarta: Indeks. 
Kotler, P. \& Armstrong, G., (2014). Principles of Marketing. 15th edition. New Jersey: Pearson-Prentice Hall.

Lubis, U. (2017). Ekonomi Digital Di ASEAN Diprediksi Capai US\$ 200 Miliar. Retrieved Mei 10, 2018, from https://www.rappler.com/indonesia/berita/bisnis/178046-ekonomi-digital-aseancapai-us\$-200-miliar.

Lupiyoadi (2001). Manajemen Pemasaran Jasa (Teori dan Praktek). Edisi I. Jakarta: Salemba Empat.

Minimarketrak (2017). Potensi Bisnis Minimarket 2018. Retrieved Mei 10, 2018, from https://www.minimarketrak.com/blog/potensi-bisnis-minimarket.

Mujiroh (2005). Analisa Pengaruh Produk, Pelayanan, dan Lokasi Terhadap Keputusan Pembelian Konsumen Pasar Swalayan Indo Rizky Purbalingga. Universitas Negeri Semarang. Retrieved from http://lib.unnes.ac.id/512.

Munandar (2001). Psikologi Industri dan Organisasi. Jakarta: UI Press.

Munawaroh, M. (2013). Manajemen Operasi. Yogyakarta: LP3M UMY.

Putra, A. \& Sunarti (2010). Pengaruh Kualitas Produk Terhadap Keputusan Pembelian dan Dampaknya Terhadap Kepuasan Pelanggan (Survei pada Mahasiswa Administrasi Bisnis Fakultas Ilmu Administrasi Angkatan 2013 dan 2014 Universitas Brawijaya yang Melakukan Pembelian Paket Data Kampus). Jurnal Administrasi Bisnis (JAB), 48(1). 124-131.

Rahman, D.N. (2013). Analisis Pengaruh Layanan, Fasilitas, Persepsi Harga, dan Lokasi Terhadap Kepuasan Pelanggan Pemancingan Ngrembel Asri Gunungpati Semarang. UNNES. Retrieved from http://lib.unnes.ac.id/18038.

Ridwan, M. \& Palupiningdyah (2014). Pengaruh Nilai Emosional, Sosial dan Kualitas Terhadap Kepuasan Konsumen. Management Analysis Journal, 3(1), 1-6. https://doi.org/10.15294/maj.v3i1.3310.

Roisah, \& Riana (2016). Telaah Hubungan Citra Merek, Kualitas Produk dan Keputusan Pembelian Konsumen. Jurnal Ekonomi, Manajemen, dan Bisnis, 4(1), 100-107. https://doi.org/10.31311/jeco.v4i1.351.

Safitri, W.T. (2017). Pengaruh Nilai Pelanggan Terhadap Kepuasan Pelanggan Pada PT. Hasjrat Abadi Cabang Kendari. Universitas Halu Oleo. Retrieved from http://sitedi.uho.ac.id/BIB213038.

Saputri, S.A., Fattah, A., \& Istanti, E. (2017). Pengaruh Emosional, Nilai Pengorbanan dan Loyalitas Merek Terhadap Kepuasaan Konsumen McDonald di Sidoarjo. EJurnal Ekonomi Bisnis Universitas Bhayangkara Surabaya, 3(2). 152-163.

Setianingsih \& Nurhadi. (2016). The Influence Of Price Perception, Product Diversity, And Store Atmosphere Toward Purchase Decision (Case Study At Dunkin Donuts Consumer In Ambarukmo Plaza Yogyakarta). Jurnal Manajemen Bisnis Indonesia (JMBI), 5(1). 82-90.

Setiawan, S. R. D. (2018). Januari 2018 Penjualan Eceran Mengalami Penurunan. Retrieved Juni 15, 2018, from https://ekonomi.kompas.com/read/2018/03/09/ 184514026/januari-2018-penjualan-eceran-mengalami-penurunan. 
Simamarta, H.M.P., Saragih, D.Y., \& Panjaitan, N.J. (2018). Peningkatan Kualitas Layanan Untuk Kepuasan Pelanggan Hotel. Jurnal Ekonomi dan Bisnis (EK\&BI), (S.1.), 1(1), 43-51.

Siregar (2012). Analisa Kualitas Produk dan Nilai Emosional Terhadap Keputusan Membeli Jittlada Thai Cuisine Cambridge. Universitas Negeri Medan. Retrieved from http://digilib.unimed.ac.id/12818/5/708221084.

Sudarso (2016). Layanan, Fungsional, Emosional, dan Kepuasan Konsumen: Sebuah Studi Kasus. Jurnal Ekonomi Bisnis dan Kewirausahaan, 5(3), 165-178.

Suhari (2008). Keputusan Pembelian Online dan Faktor-Faktor yang Mempengaruhi. Jurnal Teknologi Informasi DINAMIK, 3(2), 140-146.

Pancaningrum, E. (2017). Visual Merchandise dan Atmosfer Toko: Pengaruhnya Terhadap Keputusan Pembelian Impuls. Jurnal Ilmu Ekonomi dan Pembangunan (JIEP), 17(1). 23-40. http://dx.doi.org/10.20961/jiep.v17i1.8502.

Priyatno (2009). SPSS Untuk Analisis Korelasi, Regresi, dan Multivariate. Yogyakarta: Gava Medika.

Schiffman \& Kanuk. (2004). Consumer Behavior. 8th edition. New Jersey: Pearson Education Inc., Upper Saddle River, Prentice-Hall, Inc.

Sugiyono (2008). Metode Penelitian Bisnis. Bandung: Alfabeta.

Tjiptono, F. (2005). Manajemen Jasa. Edisi I. Yogyakarta: Bayumedia Publishing.

Tjiptono, F. (2010). Strategi Pemasaran. Edisi II. Yogyakarta: Andi Offset.

Tjiptono, F. (2012). Service Manajemen, Mewujudkan Layanan Prima. Yogyakarta: Andi Offset.

Umar (2005). Riset pemasaran dan Perilaku Konsumen. Jakarta: Gramedia Pustaka Utama.

Windasuri, H. \& Hyacintha, H. (2017). Excellent Service. Jakarta: Gramedia Pustaka Utama.

Wong \& Aspinwall (2004). Knowledge management implementation frameworks: A review. Knowledge and Process Management, The Journal of Corporate Transformation, 11(2). 93-104. https://doi.org/10.1002/kpm.193.

Yogyakartagardena. (2018). Ceremonial Hut 40 Tahun Gardena Jogja. Retrieved Mei 10, 2018, from http://yogyakarta.gardena.co.id/berita-9-ceremonial-hut-40-tahungardena-jogja. 